Review Article

\title{
A REVIEW ON GENETIC DIVERSITY OF WILD PLANTS BY USING DIFFERENT GENETIC MARKERS
}

\author{
Shazia Saeed, ${ }^{\mathrm{a}}$ and Muhammad Younas Khan Barozai, ${ }^{\mathrm{a}}$ \\ ${ }^{a}$ Department of Botany University of Balochistan, Quetta, Pakistan. \\ *Corresponding author: barozaikhan@ gmail.com
}

\begin{abstract}
Biodiversity is the variation of life at all levels of biological organization. One of the important components of biological diversity is the genetic diversity. Genetic diversity refers to the variation of genes or entire genome within and between populations of organisms. Keeping in view the significance of genetic diversity in wild plants, some research articles based on important wild plant genera and species of angiosperms including few rare, threatened, endemic, medicinal and economically important from different regions of the world are reviewed. The genetic diversity of plant species depends on different factors i.e. ecological, geographical, breeding system \& anthropogenic effects. High genetic diversity is observed at species level even in small sized population by using AFLP, SSR, \& ISSR genetic markers.
\end{abstract}

Keywords: Genetic Diversity; Genetic Structure; Genetic Markers; Species diversity; wild plants

\author{
Abbreviations: \\ AFLP Amplified fragment length polymorphism \\ DArT Diversity Arrays technology \\ ISSR Inter simple sequence repeat \\ RAPD Rapid amplification polymorphism of DNA \\ RFLP Restriction fragment length polymorphism \\ SSR Simple sequence repeat
}

\section{Introduction}

Biodiversity is the variation of life at all levels of biological organizations [1]. Biodiversity may also be defined as the "totality of genes, species, and ecosystems of a region" [2].

Genetic diversity is one of the important constituent of biological diversity. Research on biological diversity explains the species diversity within diverse ecosystems can help exploring genetic diversity and genetic structure of a specific population can provide a molecular basis for understanding its biological characteristics, phylogeny and adaptive potential. DNA markers are considered to be the most suitable means for estimating genetic diversity because of their abundant polymorphism and the fact that they are independent of environmental conditions [3-5].

\section{Genetic Structure}

Reproductive characters and population history mainly determine the genetic diversity in plant populations [6-7]. The influence of the plant's mating system affect the Plant reproductive characters and population genetic structure [8]. Mostly inbreeding species have homozygosity and lesser genetic diversity within populations and higher genetic differentiation among populations compared without crossing species [8].

It reveals to a certain degree that the relative rates of inbreeding and out crossing in species are relevant to the genetic diversity within and among populations. Population history, including the phylogeney and biogeography of a species as well as fluctuations in the number of populations may also play a significant role in the formation of its current genetic composition [6]. Existing biogeographic patterns of genetic diversity are determined by historical patterns of gene flow among populations [9-11]. Thus, the genetic structure of a species can explain its evolutionary history [12]. 


\section{Connections between species diversity and genetic Diversity}

Species diversity and genetic diversity can be defined and measured in a number of different ways.

Species diversity is most often measured as species richness, the number of species in a given locality. In studies that experimentally manipulate species diversity[13](reviewed by Loreau et al.,2001) mostly species richness varied among treatments. Many studies of species diversity integrate information about the relative abundances of species in a region, with higher diversity indicated by a more even distribution of abundance among species higher evenness [14].

In population genetics and community ecology species diversity and genetic diversity are important constituents along with ecological diversity. Species diversity within communities and genetic diversity within populations are thought to be different in space or time because of their habitat that influence the two levels of diversity by similar processes, or because of direct effects of one level of diversity on the other by means of several different mechanisms. A species diversity-genetic diversity relationship is supported by a number of theories and experimental studies, and several modern studies support this connection. Emphasizing on all possible associations between these two domains help in better understanding and synthesis at the ecological and phylogenetic aspects of systematics and biodiversity research at the levels of genes and species [15].

\section{Genetic Markers}

A genetic marker is a sequence of DNA or a gene, present on a chromosome [16-17]. Markers make it possible to detect differences between individuals by showing polymorphism, and therefore detecting genetic differences between individual organisms or species [16].

DNA markers are used in many different areas, such as genetic mapping, finding mutant genes which are connected to hereditary diseases, paternal tests, individual identification, epidemiology and food safety, population history, population studies, etc [18].

The studies may use RFLPs, RAPDs, AFLPs or SSRs. It is important to understand the properties of different markers that will reveal different aspects of genetic diversity [19].

Polyploidy, the presence of more than two sets of chromosomes within an organism, is a pervasive phenomenon in flowering plants [20-22].
Polyploids are typically grouped into autopolyploids (produced by multiplication of a single genome) and allopolyploids (combination of two or more divergent genomes). In a successful allopolyploid, two parental genomes must function within a common cytoplasm, which may be associated with numerous genetic, epigenetic, and transcriptomic changes [23-25].

\section{Diversity Arrays Technology (DArT)}

Diversity Arrays Technology (DArT) can detect and type DNA variation at several hundred genomic loci in parallel without relying on sequence information. it can be effectively applied to genetic mapping and diversity analyses of barley, a species with a 5,000-Mbp genome [26].

\section{Herbarium specimens as a source of DNA for AFLP fingerprinting}

Herbarium collections are a valuable source of genetic information. Even though the DNA obtained from the specimens is often highly fragmented and present in small quantities, it has been successfully used particularly for DNA sequencing and microsatellite analysis. The present study shows that the quality is often sufficient for use also for AFLPs. With this technique, a considerable number of DNA fragments with unknown sequence from the entire genome of the plant are amplified, often with the purpose of phylogeographic studies or analyses of interrelationships of closely related species [27].

\section{Microsatellites or simple sequence repeats (SSRs)}

These are short (1-8 bp) repeat motifs usually associated with a high level of frequency of length polymorphism. SSR markers are one of the best choices for genetic research and breeding with the advantages of their stability, PCR-based and relatively low cost. SSR markers can be developed experimentally [28].

\section{Inter-simple sequence repeats (ISSRs)}

These are regions found between microsatellite repeats, ISSR have been used since 1994 for a wide range of organisms [5] in DNA fingerprinting, diversity analysis and genome mapping [29-30]. The advantages of using ISSR are that it is quick, easy to apply, highly reproducible and polymorphous. The major significance is that no prior information about genomic sequence is required [29]. 
Table-1: Reported wild plant species for genetic diversity from different regions of the world.

\begin{tabular}{|l|l|l|}
\hline Plant Name & Country & References \\
\hline $\begin{array}{l}\text { Rheumofficinale } \\
\text { Baill., }\end{array}$ & China & $\begin{array}{l}\text { Wang } \text { et al., } \\
2012[31]\end{array}$ \\
\hline $\begin{array}{l}\text { Rhodiola rosea } \\
\text { L. }\end{array}$ & $\begin{array}{l}\text { Sweden/Greenland/Faroe } \\
\text { Islands }\end{array}$ & Kylin, M. 2010 [32] \\
\hline $\begin{array}{l}\text { Saruma henryi } \\
\text { Oliv. }\end{array}$ & China & $\begin{array}{l}\text { Zhou et al., 2012 } \\
{[33]}\end{array}$ \\
\hline Galium sp L. & North Eastern Europe & $\begin{array}{l}\text { Cieślak \& Szelag } \\
2010 .[34]\end{array}$ \\
\hline $\begin{array}{l}\text { Caragana sp } \\
\text { Fabr. }\end{array}$ & China & $\begin{array}{l}\text { Yang et al., 2012. } \\
{[35]}\end{array}$ \\
\hline Malus sp L. & China & $\begin{array}{l}\text { Zhang et al., 2011. } \\
{[36]}\end{array}$ \\
\hline
\end{tabular}

\section{Conclusion}

Study and analysis of genetic diversity by using different genetic markers resulted in the form of polymorphic bands, Shannon's information index and other tools, help in understanding the genetic variability of species within and between populations. Genetic diversity of endemic, narrow endemic and endangered species can be conserved by ex-situ and in-situ conservation strategies. Germplasm preservation, seed bank, gene bank management and sustainable development can also be accomplished by appropriate utilization of genetic diversity.

There is a dire need for all those interested in plant genetic resources conservation, needs better understanding of genetic diversity at all levels.

\section{References}

1. Gaston, K. J. \& J. I. Spicer. 2004. Biodiversity: An introduction. Blackwell Publishing. 2., ISBN 1-4051-1857-1.

2. Tor-Björn Larsson (2001). Biodiversity evaluation tools for European forests. WileyBlackwell. p. 178. ISBN 978-87-16-16434-6. Retrieved 28 June 2011.

3. Holderegger, R. U. Kamm and F. Gugerli. 2006. Adaptive vs. neutral genetic diversity: implications for landscape genetics. Landscape Ecol., 21: 797-807.

4. Esselman, E.J., J.Q. Li, D.J. Crawford, J.L. Winduss, A.D. Wolfe. 1999. Clonal diversity in the rare Calamagrostis porteri ssp. Insperata (Poaceae): comparative results for allozymes and random amplified polymorphic DNA (RAPD) and intersimple sequence repeat (ISSR) markers. Mol Ecol., 8: 443-451.

5. Zietkiewicz, E., A. Rafalski and D. Labuda. 1994. Genome fingerprinting by simple sequence repeat (SSR)-anchored polymerase chain reaction amplification. Genomics, 20: 176-183.
Table-1: : Parts used for DNA extraction to study genetic diversity and Consequences of reported wild plants

\begin{tabular}{|c|c|c|c|c|}
\hline $\begin{array}{l}\text { Plant } \\
\text { Name } \\
\end{array}$ & $\begin{array}{l}\text { Parts } \\
\text { used }\end{array}$ & $\begin{array}{l}\text { Marker } \\
\text { S used }\end{array}$ & Results & $\begin{array}{l}\text { Refere } \\
\text { nces }\end{array}$ \\
\hline $\begin{array}{l}\text { Rheum } \\
\text { officinale } \\
\text { Baill. }\end{array}$ & $\begin{array}{l}\text { Dried } \\
\text { roots } \\
\text { and } \\
\text { rhizomes }\end{array}$ & ISSR & $\begin{array}{l}\text { Results revealed high } \\
\text { genetic diversity at } \\
\text { spp.level. PPB } \\
\text { obtained were } 95.24 \%\end{array}$ & $\begin{array}{l}\text { Wang } \\
\text { et al., } \\
{[31]} \\
2012 \\
\end{array}$ \\
\hline $\begin{array}{l}\text { Rhodiola } \\
\text { rosea L. }\end{array}$ & Leaves & $\begin{array}{l}\text { SSR \& } \\
\text { ISSR }\end{array}$ & $\begin{array}{l}\text { An average } \\
\text { PPB for ISSR } \\
\text { were } 75.68 \% \\
\text { Highest in } \\
\text { Greenland as } \\
\text { compare to } \\
\text { other study } \\
\text { areas. } \\
\end{array}$ & $\begin{array}{l}\text { Kylin, } \\
\text { M. } \\
{[32]} \\
2010\end{array}$ \\
\hline $\begin{array}{l}\text { Saruma } \\
\text { henryi } \\
\text { Oliv. }\end{array}$ & Leaves & SSR & $\begin{array}{l}\text { High genetic diversity at } \\
\text { spp. Level is being } \\
\text { observed. }\end{array}$ & $\begin{array}{l}\text { Zhou et } \\
\text { al., } \\
{[33]} \\
2012 \text {. }\end{array}$ \\
\hline $\begin{array}{l}\text { Galium } \\
\text { sp } \\
\text { L. }\end{array}$ & $\begin{array}{l}\text { Leaves } \\
\text { of young } \\
\text { plants }\end{array}$ & AFLP & $\begin{array}{l}\text { Results indicate high } \\
\text { level of genetic } \\
\text { variation in all } 3 \text { species } \\
\text { studied, despite of the } \\
\text { small area occupied } \\
\text { and low population. }\end{array}$ & $\begin{array}{l}\text { Cieśla } \\
\text { k \& } \\
\text { Szelag } \\
2010 . \\
{[34]}\end{array}$ \\
\hline $\begin{array}{l}\text { Caragana } \\
\text { sp Fabr. }\end{array}$ & $\begin{array}{l}\text { Fresh } \\
\text { leaves }\end{array}$ & ISSR & $\begin{array}{l}\text { Results of genetic } \\
\text { diversity of eight } \\
\text { Caragna spp. by using } \\
\text { ISSR markers helped } \\
\text { understanding high } \\
\text { genetic diversity of all } \\
\text { spp. Studied with max. } \\
\text { PPB i.e. } 100 \% \text {. } \\
\end{array}$ & $\begin{array}{l}\text { Yang } \\
\text { et al., } \\
2012 . \\
{[35]}\end{array}$ \\
\hline $\begin{array}{l}\text { Malus sp } \\
\text { L. }\end{array}$ & $\begin{array}{c}\text { Leaf } \\
\text { Tissues }\end{array}$ & SSR & $\begin{array}{l}29 \text { Malus accessions } \\
\text { were analysed resulting } \\
\text { in } 62.5 \% \text { unique } \\
\text { alleles } \\
\text { Indicating high genetic } \\
\text { diversity can be used } \\
\text { by horticulturist and } \\
\text { plant breeders. }\end{array}$ & $\begin{array}{l}\text { Zhang } \\
\text { et al., } \\
2011 . \\
{[36]}\end{array}$ \\
\hline
\end{tabular}

6. Schaal BA, Hayworth DA, Olsen KM, Rauscher JT, Smith WA (1998) Phylogeographic studies in plants: problems and prospects. Mol Ecol 7:465474.

7. Ge X-J, Zhou X-L, Li Z-C, Hsu T-W, Schaal BA, Tzen-Yuh C (2005) Low genetic diversity andsignificant population structuring in the relict Amentotaxus argotaenia complex (Taxaceae) base on ISSR fingerprinting. J

Res 118: 415-422.

8. Hamrick, J.L. and M.J.W. Godt. 1996. Effects of life history traits on genetic diversity in plant species. Philos Trans $R$ Soc Lond B. 351:12911298

9 Hewitt, G. M. 1996. Some genetic consequences of ice ages, and their role in divergence and speciation. Bot J Linn Soc., 58: 247-276.

10 Soltis, D., M. Gitzendanner, D. Strenge and P. Soltis. 1997. Chloroplast DNA intraspecific phylogeography of plants from the Pacific Northwest of North America. Plant Syst Evol., 206: 353-373. 
11 Avise, J.C. 2000. Phylogeography: the history and formation of species. Harvard University Press,Cambridge, MA.

12 Bauert, M.R., M. Kalin, M. Baltisberger and P.J. Edwards. 1998. No genetic variation detected within isolatedrelict populations of Saxifraga cernua in the Alps using RAPD markers. Mol Ecol., 7: 1519-1527.

13 Loreau, M., S. Naeem, P. Inchausti, J. Bengtsson, J.P. Grime, A. Hector, et al. 2001. Biodiversity and ecosystem functioning: current knowledge and future challenges. Science, 294: 804-808.

14 Magurran, A.E. .2004. Measuring Biological Diversity. Blackwell Publishing, Oxford, UK.

15 Vellend, M. and M. A. Geber. 2005. Connections between species diversity and genetic diversity. Ecology Letters. 8: 767-781.

16 Collard, B.C.Y., M.Z.Z. Jahufer, and E.C.K. Pang. 2005. An introduction to markers, quantitative trait loci (QTL) mapping and marker-assissted selection for crop improvement: The basic con-cepts. Euphytica, 142(1-2): 169-196.

17 Schulmann, A.H., 2007. Molecular markers to assess genetic diversity. Euphytica, 158(3): 313 321.

18 Hartl, D.L. and E.W. Jones. 2005. DNA Structure and DNA manipulation. In Genetics: analysis of genes and genomes. Sudbury: Jones and Bartlett Pub.5: 36-85.

19 Karp, A. and K.J. Edwards. 1995 Molecular techniques in the analysis of the extent and distribution of genetic diversity. IPGRI Workshop on Molecular Genetic Tools in Plant Genetic Resources, 9-11 October, Rome, IPGRI.

20 Masterson, J. 1994. Stomatal size in fossil plants: evidence for polyploidy in majority of angiosperms. Science, 264: 421-424.

21 Leitch, A.R. and I.J. Leitch. 2008. Genomic plasticity and the diversity of polyploid plants. Science, 320:481-483.

22 Soltis, P.S. and D.E. Soltis. 2009. The role of hybridization in plant speciation. Ann Rev Plant Biol 60:561-588.

23 Liu. B. and J.F. Wendel. 2003. Epigenetic phenomena and the evolution of plant allopolyploids. Mol Phylogenet Evol., 29:365-379.

24 Chen, Z.J. 2007. Genetic and epigenetic mechanisms for gene expression and phenotypic variation in plant polyploids. Annu Rev Plant Biol., 58: 377-406.

25 Doyle. J.J., L.E. Flagel, A.H. Paterson, R.A. Rapp, D.E. Soltis, P.S. Soltis and J.F. Wendel. 2008 Evolutionary genetics of genome merger and doubling in plants. Annu Rev Genet., 42: 443-461.

26 Wenzl, P., J. Carling, D. Kudrna, D. Jaccoud, E. Huttner, A. Kleinhofs. and Andrzej Kilian. 2004. Diversity Arrays Technology (DArT) for whole- genome profiling of barley. PNAS., 101(26): 99159920.

27 Lambertini, C., J. Frydenberg, M. H. G. Gustafsson and H. Brix. 2008. Herbarium specimens as a source of DNA for AFLP fingerprinting of Phragmites (Poaceae): possibilities and limitations. Pl Syst Evol. 272: 223-231.

28 Li CD, Fatokun CA, Ubi B, Singh BB, Scoles GJ (2001). Determining genetic similarities and relationships among cowpea breeding lines and cultivars by microsatellite markers. Crop Sci 41:189-197

29 Bornet, B. \& Branchard, M., 2001. Nonanchored inter simple sequence repeat (ISSR) markers: Reproducible and specific tools for genome fingerprinting. Plant Molecular Biology Reporter, 19(3), pp. 209-215.

30 de Vicente, M.C., López, C., \& Fulton T., 2004. Genetic Diversity Analysis with Molecular Marker Data: Learning Module. [Online] IPGRI, Rome, Italy and Institute for Genetic Diversity, Ithaca, New York, USA. Available at: http://www.bioversityinternational.org/publications /molecular_markers_module_volume_2_en.html [Accessed 4 May 2010].

31 Wang, Xu. Mei. Xiao-Qi Hou, Yu-Qu Zhang, Rui Yang, Shi-Fang Feng, Yan Li, and Yi Ren. 2012.Genetic Diversity of the Endemic and Medicinally Important Plant Rheum officinale as Revealed by Inter-Simpe Sequence Repeat (ISSR) Markers. Int J Mol Sci.13(3): 3900-3915.

32 Kylin, M. 2010. Genetic diversity of Roseroot (Rhodiola rosea L.) from Sweden, Greenland and Faroe Islands. Master's thesis in Biology. Swedish University of Agricultural Sciences.

33 Zhao T.H, S.S. Dong, S. Li, G-F. Zhao. 2012.Genetic Structure Within and Among Populations of Saruma henryi, an Endangered Plant Endemic to China. Biochem Genet. 50: 146-158.

34 Cieslak and Szelag 2010. Genetic diversity of Galium cracoviense, $G$. oelandicum and $G$. sudeticum (Rubiaceae)-Narrow endemic species of Galium sect. Leptogalium in northeastern Europe. Acta societatis Botanicorum Poloniae. 79(4): 269275.

35 Yang, J., J. Yang. M. Yang. and H. Qing. 2012. Genetic diversity of Caragana species of the Ordos Plateau in China. Plant Syst Evol. 298:801-809.

36 Zhang, Q., J. Li., Y. Zhao., S. S. Korban and Y. Han. 2012. Evaluation of Genetic Diversity in Chinese Wild Apple Species along with cultivars using SSR Markers. Plant Mol Biol Rep., 30: 539546. 